\title{
Basement Geology of the National Petroleum Reserve Alaska (NPRA), Northern Alaska
}

by R.W. Saltus ${ }^{1}$, T.L. Hudson ${ }^{2}$, J.D. Phillips ${ }^{1}$, C. Kulander ${ }^{1}$, J. Dumoulin ${ }^{3}$, and C. Potter ${ }^{1}$

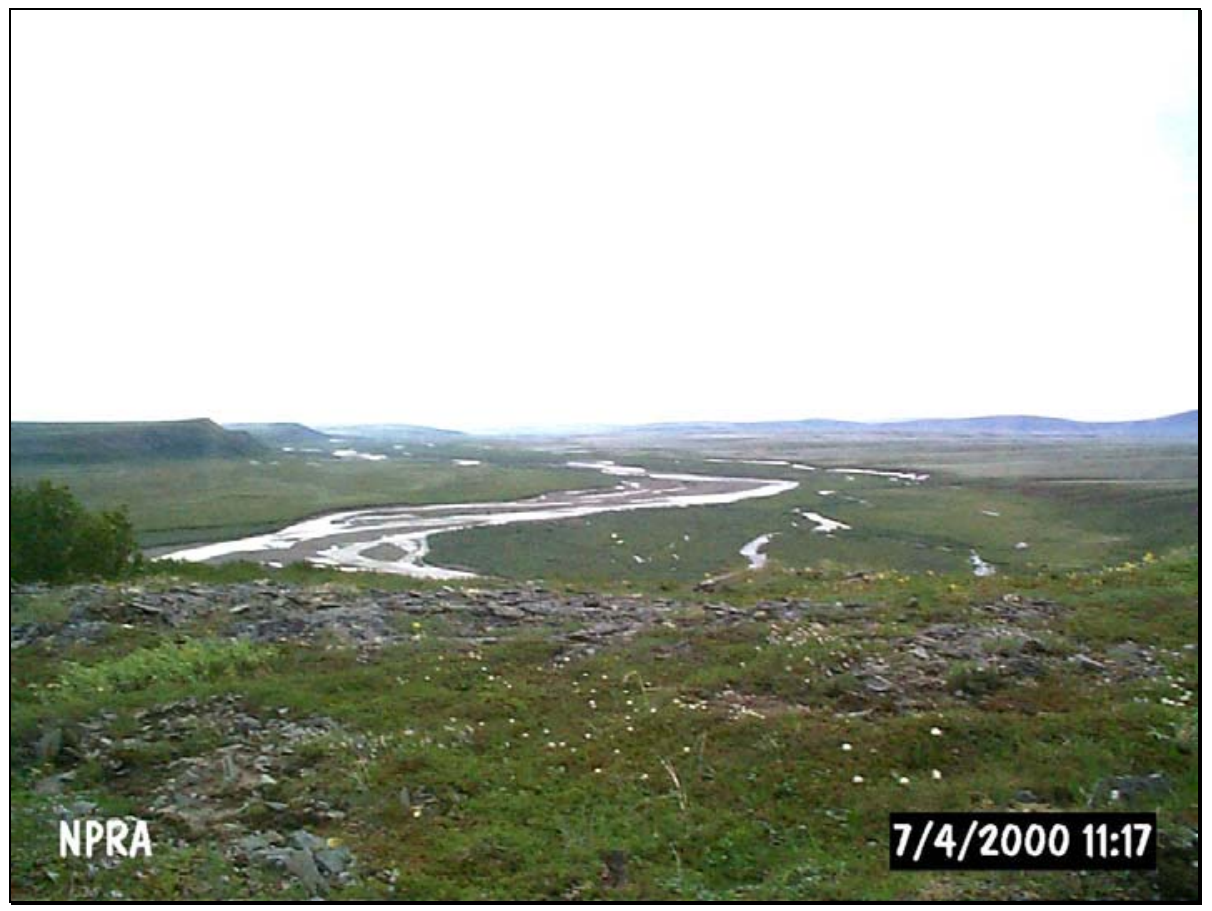

Open-File Report 02-0127

2002

This report is preliminary and has not been reviewed for conformity with U.S. Geological Survey editorial standards or with the North American Stratigraphic Code. Any use of trade, firm, or product names is for descriptive purposes only and does not imply endorsement by the U.S. Government.

\section{U.S. DEPARTMENT OF THE INTERIOR}

U.S. GEOLOGICAL SURVEY

${ }^{1}$ U.S. Geological Survey, Denver, Colorado

${ }^{2}$ Applied Geology, Inc., Sequim, WA.

${ }^{3}$ U.S. Geological Survey, Anchorage, Alaska 


\section{Abstract}

Gravity, aeromagnetic, seismic, and borehole information enable mapping of crustal basement characteristics within the National Petroleum Reserve Alaska (NPRA). In general, the pre-Mississippian basement of the southern portion of the NPRA is different from that in the north in that it is deeper and thinner, is made up of dense magnetic rocks, is cut by more normal faults, and underlies thicker accumulations of Mississippian to Triassic Ellesmerian sequence sedimentary rocks. Mafic igneous rocks within the basement and locally within the deeper Ellesmerian sequence sedimentary section could explain the observed density and magnetic variations. Because these variations spatially overlap thicker Ellesmerian sequence sediment accumulations, they may have developed, at least in part, during Mississippian to Triassic extension and basin formation. If this period of extension, and postulated mafic magmatism, was accompanied by higher heat flow, then early Ellesmerian sequence clastic sediments may have become mature for hydrocarbon generation (Magoon and Bird, 1988). This could have produced an early petroleum system in the Colville basin.

\section{Introduction}

A thick mantle of Mississippian to Cenozoic sedimentary rocks overlies the preMississippian basement rocks in the Colville basin north of the Brooks Range in northern Alaska (Figure 1). These rocks are divided into three primary sequences based on provenance: 1) the lower Cretaceous to recent Brookian sequence with its source to the south, 2) the Jurassic to lower Cretaceous Beaufortian sequence with sources dominantly from the north, and 3) the Mississippian to Triassic Ellesmerian sequence with sources to the north (Moore and others, 1994; Figure 2).

One basement feature in the northern part of the National Petroleum Reserve of Alaska (NPRA), the basement-cored Barrow Arch, is well known to have influenced regional stratigraphic development (e.g., Kirschner and Rycerski, 1988). Structural mapping based primarily on a regional network of seismic reflection data (Bruynzeel and others, 1982) has delineated many other features developed on or within NPRA basement (Plate 1) including areas of thin (Meade Arch) and thick (Meade, Ikpikpuk, and Umiat basins) Ellesmerian sequence sedimentary rocks, and basement-involved normal faulting.

The North Slope deep magnetic high (Saltus and others, 1999b) is the most prominent magnetic feature of NPRA. This broad magnetic high is the largest individual, onshore Alaska domain of intense magnetic highs outside of the southern Alaska region (Saltus and others, 1999b). Originally mapped in 1945 in the first regional aeromagnetic survey flown over land (Payne and others, 1952), the North Slope deep magnetic high is a crustal-scale feature that underlies southern NPRA and continues south and east under other parts of northern Alaska.

This study integrates gravity, magnetic, seismic, and borehole information that bear on the major basement domains within NPRA. The regional presence of dense and magnetic rocks in the basement is required to explain many of the observed gravity and magnetic features. The inferred physical property patterns in the basement coincide with patterns 
in the overlying sedimentary basin development, especially variations in the thickness of Ellesmerian sequence sedimentary rocks.

\section{Gravity evidence for basement density variations}

Three-dimensional spatial variations in subsurface rock density cause surface gravity variations. We have made use of extensive knowledge of the thickness and physical properties of Mississippian and younger rocks (from seismic interpretation and borehole studies) to calculate the expected gravity effect of these rocks. When this "basin gravity" is subtracted from the observed surface gravity, the result is the "basement gravity" - the predicted gravity effect of density variations within the pre-Mississippian basement rocks (Saltus and others, 2001a).

Examination of basement gravity yields some broad-scale conclusions about the basement in the NPRA region of northern Alaska (Saltus and others, 2001a). In the northern part of NPRA, the basement produces gravity anomalies consistent with normal sialic crustal densities. In the southern part of NPRA, the basement produces gravity anomalies consistent with a denser, more mafic composition. In the southern part of the study area, in the Brooks Range foothills, the gravity model is less reliable because of uncertainties in seismic interpretation relating to complicated over-thrusting (Saltus and others, 2001a), but also suggests the presence of dense basement rocks.

On a more local scale, an elliptical basement gravity low in northern NPRA surrounds the East Teshekpuk borehole (Plate 1). This low may define the boundaries of the basement granite body penetrated in the borehole (Dumoulin and Bird, 2001; Bird and others, 1978).

\section{Aeromagnetic evidence for basement (and deep basin) mafic magnetic source rocks}

Magnetic anomalies are caused by variations in the amount and type of magnetic minerals in crustal rocks. Most sedimentary rocks are only weakly magnetic (typical susceptibilities less than $1 \times 10^{-3} \mathrm{SI}$ ). Igneous and volcanic rocks are more magnetic (often greater than $10 \times 10^{-3} \mathrm{SI}$ ). Although there are wide variations in magnetic susceptibility of igneous rocks, mafic rocks are generally more magnetic than felsic rocks. Large amplitude, crustal-scale magnetic highs require the presence of an extensive amount of mafic material within the crust.

All other things being equal, a more deeply buried magnetic source body will produce a longer wavelength (broader) anomaly than the same source body at a shallower depth. Thus, analysis of anomaly wavelengths is a general guide to source depth. Various mathematical tools that take advantage of the special properties of potential fields (such as aeromagnetic data) can be used to estimate source depths (e.g., Blakely, 1995).

The regional magnetic field of northern Alaska is dominated by the long-wavelength, high-amplitude North Slope deep magnetic high (Saltus and others, 1999b). There is no evidence for widespread, thick, and highly magnetic rocks within the basin as the primary 
magnetic sources for this high. This, combined with the smooth, long-wavelength character of the anomaly, suggests that, for the most part, its highly magnetic source is in the basement (Saltus and others, 2001a). The basement must contain a large volume of mafic rocks to produce the observed anomalies.

Although Saltus and others (2001a) concluded that most of the magnetic anomaly variation in NPRA is caused by magnetic source variations in the basement, in a few cases shorter-wavelength features of the aeromagnetic data lead us to conclude that magnetic sources are present within the Ellesmerian sequence rocks in deeper portions of the basin. Mafic and ultramafic rocks exposed in the western Brooks Range are possible outcrop analogs to these magnetic source rocks (Saltus and others, 2001b). The crosshatched region in Plate 1 shows the location of probable magnetic sources within the deeper Ellesmerian sequence sedimentary rocks of the basin.

\section{Basement thickness estimates}

We have estimated the total thickness of the basement rock section that extends from the seismic basement to the Moho. To the Moho estimate, we used a model of Airy isostasy (Airy, 1855; Simpson and others, 1986). With this model Moho depth is proportional to topographic height. The TACT seismic line (Fuis and others, 1997), which is east of the NPRA, is the only actual measurement of Moho depth in northern Alaska. To fit our model of Moho depth to the measured Moho depth of about $48 \mathrm{~km}$ where the TACT seismic line crosses the highest Brooks Range at Atigun Pass (Fuis and others, 1997), we assumed a Moho depth of $35 \mathrm{~km}$ beneath topography at sealevel, a topographic load density of $2.67 \mathrm{~g} / \mathrm{cm}^{3}$ (consistent with the Bouguer reduction density used), and a density contrast across the Moho of $0.35 \mathrm{~g} / \mathrm{cm}^{3}$. This model predicts a steady increase in Moho depth southward from the coast toward the topographic highs of the Brooks Range. The greatest Moho depth is in the southern portion of NPRA where the predicted depth exceeds $40 \mathrm{~km}$.

The predicted basement thickness was calculated by subtracting the Tetra Tech (Bruynzeel and others, 1982) seismic basement interface from the predicted isostatic Moho. The basement portion of the crust varies in thickness by about $20 \%$ from a maximum of more than $33 \mathrm{~km}$ in the Barrow region to a minimum of less than $26 \mathrm{~km}$ in the southwestern portion of NPRA.

\section{Geophysical domains}

The yellow, peach, and salmon colored regions (Plate 1) indicate three basement domains based on the geophysical data. The black contour lines (Plate 1) show basement thickness. The northern domain is a region of low-to-neutral basement gravity, shallow depth-to-basement, thick sub-basin crust, and low-to-moderate inferred basement magnetization. The central domain is a region of high basement gravity, intermediate depth-to-basement, thinnest sub-basin crust, and moderate basement magnetization. The southern domain is a region of neutral-to-high basement gravity, greatest depth-tobasement, thin sub-basin crust, and high basement magnetization. 


\section{Upper basement features}

The top of NPRA basement generally deepens to the south from structurally high levels along the Barrow arch (eg., Bird, 1988, Figure 16.3). This trend is interrupted by large basinal features including the Ikpikpuk-Umiat basin complex and the Meade basin. From these basins southward, NPRA basement is cut by numerous normal faults that in places form complex horst and graben features (Kirschner and Rycerski, 1988; Bruynzeel and others, 1982). Many of the normal faults are within the Ikpikpuk, Umiat, and Meade basins (Kirschner and Rycerski, 1988). In general, large northwest- to west-trending normal faults are well developed in the basement across all of southern NPRA (Bruynzeel and others, 1982). In southwest NPRA, the basement normal faults strike northwest and trend toward the offshore Hannah trough in the Chukchi Sea (Grantz and others, 1988). Normal fault development in NPRA basement continues southward as far as seismic data allow reliable interpretation (eg., Bird, 1988, Figure 16.3; Plate 1). Because some of the normal faults die out up-section in the lower Lisburne Group, the age of basement-involved normal faulting is interpreted to be as young as Late Devonian and /or Early Mississippian (Kirschner and Rycerski, 1988).

In general there is a lack of coherent, through-going seismic reflections within the basement in most areas. In fact, many basement cores show steep to vertical dipping beds (e.g., images shown in Houseknecht, 2002). These steeply dipping beds, as old as Ordovician, overlain by relatively undisturbed Mississippian and younger strata are one of the primary pieces of evidence for a deformational event in northern Alaska in midPaleozoic time (the so-called Ellesmerian orogeny). The regional extent and trends of deformation are poorly known. Steep dips are known in the basement from the Peard well extending as far to the east as wells in the Colville delta. There does not seem to be an angular unconformity between Mississippian and older rocks within the Brooks Range south of NPRA.

Although the Brooks Range foredeep and fold and thrust belt obscure seismic imaging of basement in southernmost NPRA, some Brookian, basement-involved reverse faults have been mapped by Bruynzeel and others (1982) in southwest NPRA. However, more recent interpretation (Kulander and others, in press) disagrees with this and does not find evidence for basement involvement in Brookian thrusting.

\section{Basement lithologies}

At least 30 wells penetrate basement rocks in NPRA, but most of these are along the Barrow Arch in the northernmost study area (Dumoulin and Bird, 2001; Plate 1, this report). These wells have encountered three lithologic assemblages previously considered to be part of the NPRA basement:

1. Ordovician and Silurian argillite with local siltstone, sandstone, and chert is present along the Barrow Arch and in the Peard 1 well along the Chukchi Sea coast (Carter and Laufield, 1975).

2. Probable Devonian conglomerate, sandstone, and some carbonaceous claystone and coal are present in two wells (South Meade 1 and Topogoruk 1) south of the Barrow Arch (Plate 1). The Topagoruk basement is paleontologically dated as 
definite Devonian (early or middle; Collins, 1958). The South Meade basement is undated, but lithologic similarities with Topagoruk basement suggest a similar age.

3. Probable Devonian granite is present in the East Teshekpuk 1 well on the Barrow Arch in northeast NPRA.

Both the argillite and granitic assemblages have been tied to exposed basement rocks elsewhere in northern Alaska (Moore and others, 1994; Dumoulin and Bird, 2001). The probable Devonian conglomerate and sandstone assemblage has been correlated with other Devonian clastic rocks in the north-central and eastern Books Range and interpreted to represent initial rift basin fill deposited at the beginning of Ellesmerian sequence deposition rather than true basement (Anderson, 1993; Kelley and Brosgé, 1995). In this setting, facies discontinuities, local unconformities, and structural tilting related to basinmargin normal faulting should probably be expected. These rocks could make up significant parts of the deeper and thicker Ellesmerian depocenters such as the Ikpikpuk and Umiat basins (Plate 1). In places, they may have been included with acoustic basement as defined in the Tetra Tech (Bruynzeel and others, 1982) mapping, especially were they are steeply dipping.

\section{Discussion}

This analysis of the gravity and magnetic character of NPRA basement leads to the following general conclusions:

- Normal, sialic crustal density and magnetic properties characterize basement throughout large parts of northern NPRA.

- High densities and magnetic susceptibilities are present in basement throughout southern parts of NPRA including the Umiat basin.

Although most of the lateral variation in density and magnetic susceptibility is within NPRA basement, there are some areas where the magnetic sources must be above basement within the overlying sedimentary basin. Seismic anomalies and magnetic modeling suggest that the within-basin magnetic sources may be as high in the stratigraphic section as the Triassic Shublik Formation (Rockwell, 1978; Saltus and others, 2001a). The regions of high basement densities and magnetic susceptibilities generally coincide with areas of:

1. Extensive basement normal faulting.

2. Above average thickness of Ellesmerian sequence sedimentary rocks.

3. Up to $20 \%$ or more of apparent basement thinning relative to basement thickness to the north.

The combined geophysical and geologic relations have several implications for Ellesmerian basement development, regional magmatism, and early petroleum system evolution in NPRA. 
The $20 \%$ or more of apparent basement thinning corresponds in space, and probably in time, with Endicott Group deposition. We speculate that most of the 6 kilometers or more of apparent basement thinning accommodated at least 4 kilometers or more of above-average sedimentary thickness in the Lisburne and Endicott Groups (eg., Bird, 1988, Figures 16.10 and 16.11). Development of this accommodation space is consistent with the extensive basement-involved normal faulting that in places extends up-section to Lower Mississippian Lisburne Group stratigraphic levels (Kirschner and Rycerski, 1988). The extension and rifting of the basement that led to at least $20 \%$ basement thinning probably began in the Devonian. The Devonian coal-bearing conglomerate and sandstone present in the South Meade 1 and Topogoruk 1 wells (Dumoulin and Bird, 2001; Plate 1, this report) and vague, dipping seismic reflectors within some upper basement domains, suggests that earliest Ellesmerian basin development was in an extensional rift setting that developed at least local, coarse, nonmarine sediments as old as mid-Devonian. This early Ellesmerian section may be at least in part correlative with what Grantz and May (1988) recognize as the Eo-Ellesmerian sequence in the Chukchi Sea that can be up to 5 kilometers thick. Outcrop analogs to the early Ellesmerian section may be present in the north-central and northeast Brooks Range where Middle Devonian to Mississippian rift basin margin sediments have been recognized (Anderson, 1993; Anderson and others, 1994; Kelley and Brosgé, 1995). Although much of the early Ellesmerian sedimentation can be reasonably inferred to be clastic rocks of the Endicott Group, in a rift setting where $20 \%$ basement extension occurred, intraformational unconformities and other types of sedimentary discontinuities (e.g. Kelley and Brosgé, 1995) are to be expected. The early Ellesmerian section of NPRA probably includes at least local clastic-rich sections that may have been previously included in interpreted acoustic basement (i.e., Bruynzeel and others, 1982). The cumulative thickness of clastic-rich, early Ellesmerian sediments is probably several kilometers.

These observations fit with the overall context of the North Slope Ellesmerian sequence as an assemblage of continental margin sedimentary rocks which display proximal, shoreline and nonmarine facies in the north and distal, offshore and generally condensed facies to the south (Moore and others, 1994). Given a continental margin setting, southward crustal thinning and, eventually the possible presence of oceanic crust, is consistent.

The high density and magnetization of southern NPRA basement most likely reflects emplacement of mafic (to ultramafic) magmatic rocks. Although the geophysical interpretation do not define the nature and age of this magmatism, some general possibilities can be inferred from the NPRA Ellesmerian geologic setting, the regional geology of northern Alaska, and occurrences of mafic rock in northern Alaska. In general, the geophysical data indicate that mafic magmatism was present over a very large area that coincides with areas of basement thinning during early Ellesmerian basin development. From a regional perspective, it seems that at least four possible settings for mafic magmatism need to be considered. 
1) The igneous rocks are Devonian in age like other intrusive and volcanic rocks that are widespread through interior Alaska and the Brooks Range (Hudson, 1994). The basement granite in the East Teshekpuk well could be part of this regional magmatic suite. Although mafic components of this regional suite have been recognized, their extent seems insufficient to explain NPRA basement characteristics.

2) The magmatism is largely coeval with rifting and overlaps with early Ellesmerian sequence sedimentation. In this setting, much of the magmatism would be expected to be basaltic volcanism and therefore result in interbedded volcanic and sedimentary sequences. This possibility cannot be discounted in early Ellesmerian sections within NPRA, especially those parts that might now be included in acoustic basement. Other possibly related rocks include scattered occurrences of volcanic rocks in the Early Mississippian Kayak Shale in the central Brooks Range and basaltic sills that intrude Late Mississippian Lisburne along the mountain front in northeastern Brooks Range south of Prudhoe Bay (Moore and others, 1994). In addition wells just west of Prudhoe have intersected thin mafic dikes, sills, or flows in the Endicott and Lisburne intervals (Moore and others, 1994).

3) The magmatism might be as young as Triassic. Plutons may have emplaced into rocks as young stratigraphically as the Triassic Shublik Formation. This possibility is supported by geophysical models that indicate magnetic sources must be present within the deeper parts of the basin (Saltus and others, 2001a). Also, volcanic or intrusive rocks could explain some anomalies in seismic reflection data (Rockwell, 1978). Basalts encountered in the Permian section of the Tunalik well (Doumoulin and Bird, 2001) could relate to this event.

4) The magmatism might, at least in partially, be a part of a pre-Devonian (possibly even pre-Cambrian) intrusive episode. This possibility ties in with the observation of mafic rocks, the Mt. Coppleston volcanics, at the west end of the Shublik Mountains that underlie the pre-Cambrian Katakturuk Dolomite (Moore, 1987).

The four possible settings for mafic magmatism are not mutually exclusive but an argument can be made that the third possibility, late mafic magmatism, can explain many of the geological and geophysical relationships. Late magmatism would have occurred after several kilometers of Ellesmerian sediments had been deposited. These sediments could have provided the overburden needed to ensure that significant portions of the mafic magmas were emplaced as intrusive components in the basement as is required by much of the gravity and magnetic data. The possibility that magmatism is late is also consistent with recent interpretations of exposed mafic and ultramafic rocks in the western Brooks Range outcrop belt, just south of NPRA (Saltus and others, 2001b).

The principal implication of this geophysical analysis of NPRA basement for petroleum systems is that an early episode of maturation and migration may have occurred. The presence of up to several kilometers of early Ellesmerian shallow marine to nonmarine clastic rocks in deep parts of the North Slope basin has long been recognized (eg. Kirshner and Rycerski, 1988; Brosgé and others, 1988; Grantz and May, 1988; Kelley 
and Brosgé, 1995). The geophysical analysis requires that extensive mafic magmatism either accompanied extension during early Ellesmerian sedimentation and/or was emplaced later, as late as the Triassic. The extensional setting and inferred mafic magmatism combine to suggest that the older Ellesmerian setting in southern NPRA was one characterized by high heat flow. The overprinting of elevated temperature gradients on several kilometers of early Ellesmerian sediments may have been sufficient to mature these mostly gas-prone source rocks. If this occurred, it would have produced the an early petroleum system in the North Slope basin. In general, this possibility has, at most, only modest implications for resource assessment. However, if migration efficiencies were not well-developed, deep reservoir quality may be at least partially preserved and there may be some possibility of a deep, basin-centered gas play in southern NPRA. Sooty Ordovician-Silurian shales at Barrow with up to $10 \%$ total organic content suggest that there might have been even earlier (basement interval) petroleum system(s) operational during and just after the Ellesmerian orogeny.

\section{Conclusions}

From north to south in NPRA, the total thickness of the basement portion of the crust decreases from $32 \mathrm{~km}$ to $26 \mathrm{~km}$, a $20 \%$ decrease. This apparent thinning roughly coincides with a predicted increase in basement density from analysis of gravity data and a transition from weakly to strongly magnetized rocks. Although the denser and more magnetic rocks must be primarily in the basement, there is also evidence for magnetic source bodies extending well up into the Ellesmerian section, perhaps as high as the Triassic Shublik Formation. The thinned, dense, and strongly magnetic basement is consistent with the explanation that the region has undergone more than $20 \%$ extension and experienced extensive mafic magmatism. The development of dense and magnetic basement coincides in space, and probably in time, with above-average thicknesses of Ellesmerian sedimentary rocks. The clastic-rich early Ellesmerian sequence sedimentary rocks, including rocks that are probably similar to the Eo-Ellesmerian sequence in the Chukchi Sea (Grantz and May, 1988), may be as old as Middle Devonian and at least several kilometers thick. Some parts of this sequence have probably previously been included in acoustic basement. The geophysical data indicate that mafic magmatism was present over a very large area that coincides with areas of basement thinning during early Ellesmerian basin development. The early Ellesmerian extensional setting and extensive mafic magmatism suggests that high heat flow may have characterized this time. If increased temperature gradients were sufficient, maturation of early Ellesmerian gasprone source rocks may have occurred. This would have produced an early petroleum system in the North Slope basin.

\section{References}

Airy, G.B., 1855, On the computation of the effect of the attraction of the mountainmasses, as disturbing the apparent astronomical latitude of stations in geodetic surveys: Philosophical Transactions of the Royal Society of London, v. 145, p. 101-104.

Anderson, A. V., 1993, Stratigraphic variation across a Middle Devonian to Mississippian rift-basin margin and implications for subsequent fold and thrust geometry, 
northeastern Brooks range, Alaska: Fairbanks, Alaska, University of Alaska, Ph.D. dissertation, $276 \mathrm{p}$.

Anderson, A. V., Wallace, W. K., and Mull, C. G., 1994, Depositional record of a major tectonic transition in northern Alaska: Middle Devonian to Mississippian rift-basin margin deposits, upper Kongakut River region, eastern Brooks Range, Alaska, in Thurston, D. K., and Fujita, K., eds., 1992 Proceedings of the International Conference on Arctic Margins: U. S. Minerals Management Service Outer Continental Shelf Study, MMS 94-0040, Anchorage, Alaska, p. 71-76.

Bird, K. J., 1988, Alaskan North Slope stratigraphic nomenclature and data summary for government-drilled wells, in Gryc, G., ed., Geology and exploration of the National Petroleum Reserve in Alaska, 1974 to 1982: U. S. Geological Survey Professional Paper 1399, p. 317-354.

Bird, K. J., Connor, C. L., Tailleur, I. L., Silberman, M. L., and Christie, J. L., 1978, Granite on the Barrow arch, northeast NPRA, in Johnson, K. M., ed., The United States Geological Survey in Alaska: Accomplishments during 1977: U. S. Geological Survey Circular 772-B, p. B24-B25.

Blakely, R.J., 1995, Potential Theory in Gravity and Magnetic Applications: Cambridge University Press, New York, 441 pp.

Brosgé, W. P., Nilsen, T. H., Moore, T. E., and Dutro, J. T., Jr., 1988, Geology of the Upper Devonian and Lower Mississippian(?) Kanayut Conglomerate in the central and eastern Brooks Range, in Gryc, G., ed., Geology and exploration of the National Petroleum Reserve in Alaska, 1974 to 1982: U. S. Geological Survey Professional Paper 1399, p. 299-354.

Bruynzeel, J. W., Guldenzoph, E. C., and Pickard, J. E., 1982, Petroleum exploration of NPRA, 1974-1981-Final Report: Houston, Tetra Tech, Inc., report 8200, 3 vols., 5 boxes of geophysical maps. [Available form National Geophysical Data Center, 325 Broadway, E/GC, Dept. CNP, Boulder, CO 80303].

Carter, Claire, and Laufield, Sven, 1975, Ordovician and Silurian fossils in well cores from the North Slope of Alaska: American Association of Petroleum Geologists Bulletin, v. 59, p. 451-456.

Collins, F. R., 1958, Test wells, Topagoruk area, Alaska: U. S. Geological Survey Professional Paper 305-D, p. 265-316.

Dumoulin, J. A. and Bird, K.J., 2001, Lithologies of the basement complex (Devonian and older) in the National Petroleum Reserve - Alaska, in Houseknecht, D.W. (ed.), NPRA Core Workshop; Petroleum Plays and Systems in the National Petroleum Reserve - Alaska, SEPM Core Workshop No. 21, p. 201-214. 
Grantz, Arthur, and May, S. D., 1988, Regional geology and petroleum potential of the United States Chukchi sea self north of Point Hope, in Gryc, G., ed., Geology and exploration of the National Petroleum Reserve in Alaska, 1974 to 1982: U. S. Geological Survey Professional Paper 1399, p. 209-230.

Houseknecht, D.W., 2002, National Petroleum Reserve Alaska (NPRA), Core Images and Well Data: U.S. Geological Survey DDS-75, 4 CDROM set.

Hudson, T. L., 1994, Crustal melting events in Alaska, in, Plafker, George, and Berg, H. C., eds., The Geology of Alaska: Boulder, Colorado, Geological Society of America, The Geology of North America, v. G-1, p. 657-670.

Kelley, J. S., and Brosgé, W. P., 1995, Geologic framework of a transect of the central Brooks Range: Regional relations and an alternative to the Endicott Mountains allochthon: American Association of Petroleum Geologists Bulletin, v. 79, p. 1087-1115.

Kirschner, C. E., and Rycerski, B. A., 1988, Petroleum potential of representative stratigraphic and structural elements in National Petroleum Reserve in Alaska, in Gryc, G., ed., Geology and exploration of the National Petroleum Reserve in Alaska, 1974 to 1982: U. S. Geological Survey Professional Paper 1399, p. 191-208.

Kulander, C.S., Grow, J., Potter, C., Saltus, R., and Killgore, M., in press, Interpreted regional seismic reflection lines, National Petroleum Reserve - Alaska: in Bird and Nelson, (eds), U.S. Geological Survey E-Bulletin.

Magoon, L. B., and Bird, K. J., 1988, Evaluation of petroleum source rocks in the National Petroleum reserve in Alaska, using organic carbon content, hydrocarbon content, visual kerogen, and vitrinite reflectance, in Gryc, G., ed., Geology and exploration of the National Petroleum Reserve in Alaska, 1974 to 1982: U. S. Geological Survey Professional Paper 1399, p. 317-354.

Moore, T.E., 1987, Geochemistry and tectonic setting of some volcanic rocks of the Franklinian assemblage, central and eastern Brooks Range: in Tailleur, I., and Weimer, P., eds., Alaskan North Slope Geology, Volume, Two, Society of Economic Paleontologists and Mineralogists, p. 691-710.

Moore, T.E., Wallace, W.K., Bird, K.J., Karl, S.M., Mull, C.G., and Dillon, J.T., 1994, Geology of northern Alaska: in Plafker, G., and Berg, H.C., eds., The Geology of Alaska: DNAG volume G-1, p. 49-140.

Payne, T.G., and others, 1952, Aeromagnetic map of Naval Petroleum Reserve No. 4 (Alaska), in Geology of the Arctic slope of Alaska: U.S. Geological Survey Map OM126, 3 sheets, scale 1:1,000,000.

Rockwell, D.W., 1978, Preliminary draft of interim report on review and analysis of seismic and subsurface data from the foothills belt and adjoining portion of the coastal 
plain sector of the National Petroleum Reserve in Alaska: Stewart Folk \& Company, Inc., Houston, Technical Memo, 33 pp.

Saltus, R.W., Connard, G.G., and Hill, P.L., 1999a, Alaska aeromagnetic compilation digital grids and survey data: U.S. Geological Survey Open-File Report 99-0502, 1 CDROM.

Saltus, R.W., Hudson, T.L, and Connard, G.G., 1999b, A new magnetic view of Alaska: GSA Today, v. 9, n. 3, p. 1-6.

Saltus, R.W., Hudson, T.L., and Phillips, J.D., 2001a, Basement geophysical interpretation of the National Petroleum Reserve Alaska (NPRA), northern Alaska: U.S. Geological Survey Open-File Report 01-0476, 3 poster panels with supplementary text (http://geology.cr.usgs.gov/pub/open-file-reports/ofr-01-0476/)

Saltus R.W., Hudson, T.L., Karl, S.M., and Morin, R.L., 2001b, Rooted Brooks Range ophiolite: Implications for Cordilleran terranes: Geology, v. 29, p. 1151-1154.

Simpson, R.W., Jachens, R.C., Blakely, R.J., and Saltus, R.W., 1986, A new isostatic residual gravity map of the conterminous United States with a discussion on the significance of isostatic residual anomalies: JGR, v. 91, n. B8, p. 8348-8372. 


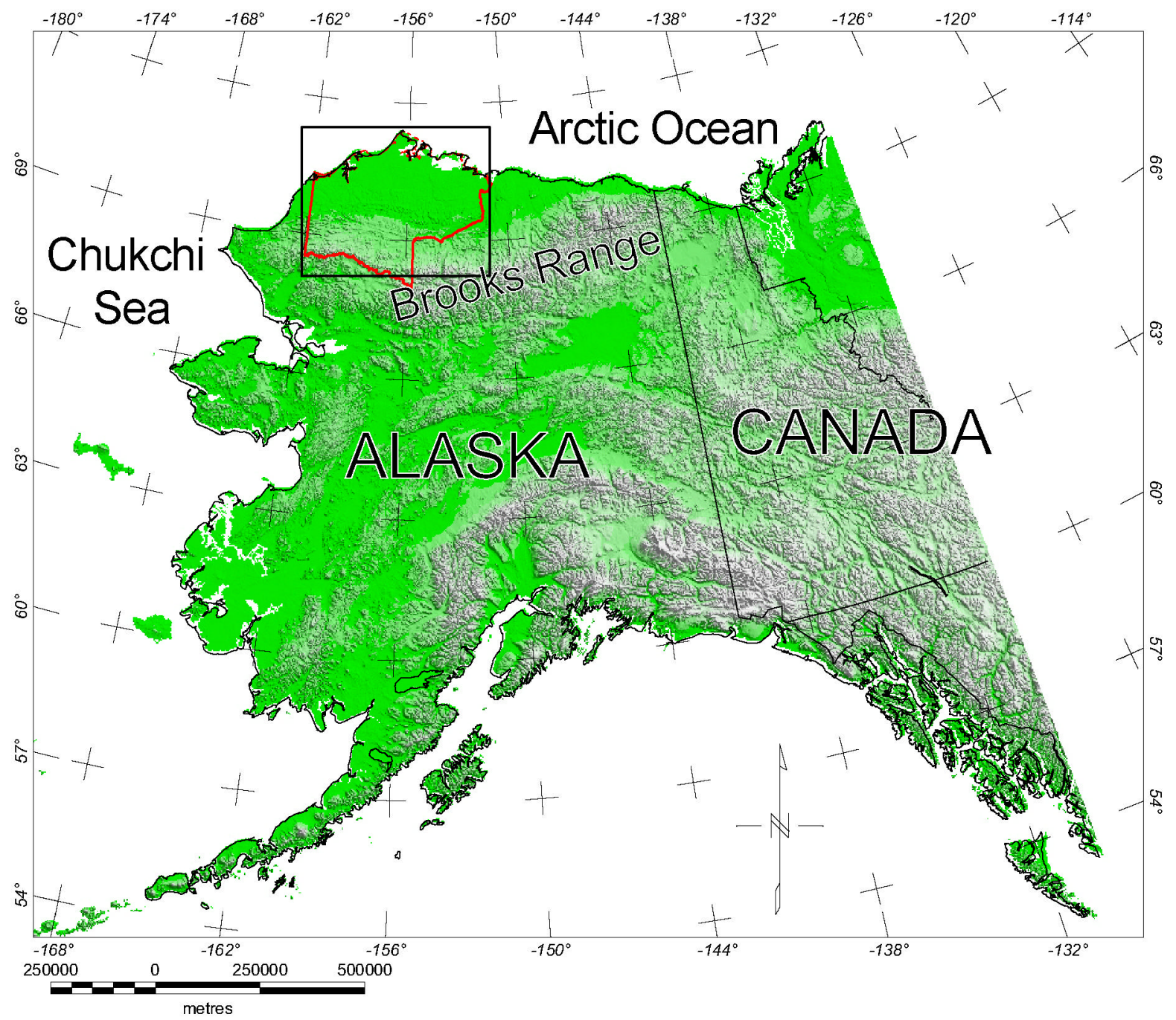

Figure 1 - Location Map. Red outline is the approximate NPRA boundary. The black rectangle shows the location for Plate 1.

USGS Open-File Report 02-0127 


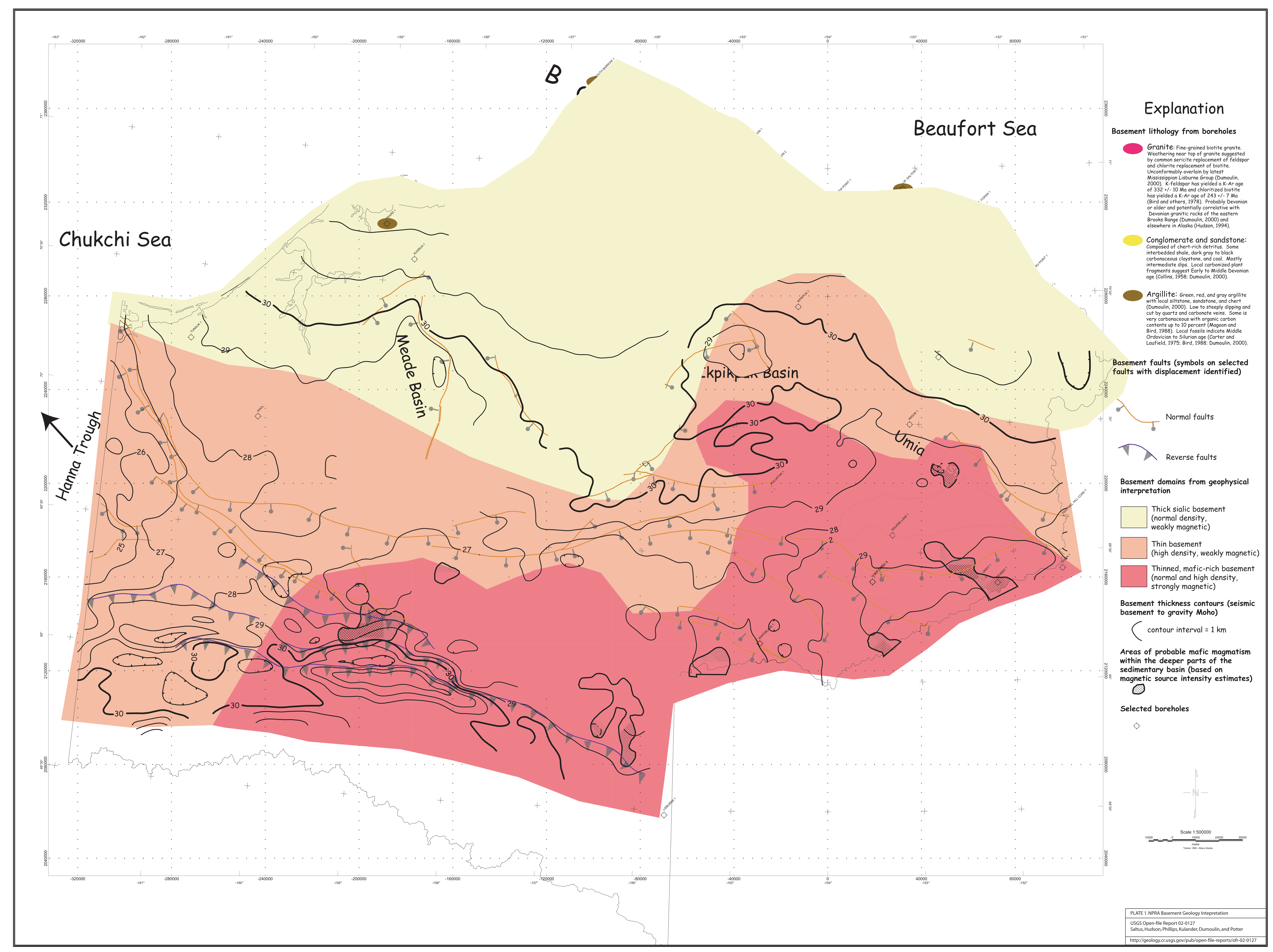

